\title{
Pendampingan Ustaż dan Tuan Guru Pesantren melalui Penguatan Nilai-nilai Multikultural untuk Mencegah Radikalisme Islam Berbasis Pesantren di Kota Bima
}

\section{Ruslan}

Institut Agama Islam Muhammadiyah Bima E-mail: ruslanamarizqi@gmail.com

\author{
Luthfiyah \\ Institut Agama Islam Muhammadiyah Bima \\ E-mail: luthfiyah.inarizqi@gmail.com
}

\section{Article History:}

Received: 2020-03-14

Revised: 2020-04-15

Accepted: 2020-05-31

\begin{abstract}
Bima city has been called "Red Zone" area for radicalism dissemination. Prior reasearch indicated that the Islamic radicalism in Bima appeared from Islamic institution such as pesantren. This community service aimed at preventing Islamic radicalism in pesantren by sharing, educating and giving reinforcement of multicultural values to ustaż and Tuan Guru Pesantren (TGP). Community-Based Research (CBR) approach was employed because ustaż and TGP are the prior of pesantren's community who can developed and transfer their understanding and religious perception to the students (santri). The results showed that ustaż and TGP had been more inclusive in their religion understanding, they transformed multicultural values to their student and all of pesantren's community until this preventive step can prohibit the Islamic radicalism. They were also willing to involve the community service team in composing pesantren's learning program. The team also give monthly visit for sharing idea about multicultural values.
\end{abstract}

Keywords: Islamic

Radicalism, Multicultural

Values, Tuan Guru

Pesantren, Ustaż Pesantren

\section{Pendahuluan}

Radikalisme Islam adalah fakta yang tidak dapat dipisahkan dari kehidupan masyarakat beragama Islam. Bahkan, Springer berpendapat bahwa radikalisme Islam bukanlah paham atau ekspresi yang kehadirannya secara tiba-tiba, melainkan ada kontinyuitas sejarah yang dipelopori oleh tokoh-tokoh intelektual (intellectual fathers) yang memiliki kesamaan tujuan dan musuh. 10 Intellectual fathers radikalisme Islam, yaitu: Ibn Taymiyyah, Muhammad bin Abdul Wahab, Rashid Ridha, Hassan Al-Banna, Abu A'la Al-Maududi, Sayid Qutb, Shukri Mustafa, Abd. Salam Al-Farag, Abdullah Azzam, Abu Muhammad Al-Maqdisi. ${ }^{1}$ Radikalisme Islam merupakan persoalan laten dalam kehidupan kolektif manusia, yang sewaktu-waktu bisa muncul dan mengacaukan

${ }^{1}$ Devin R. Springer, James L. Regens, and David N. Edger, Islamic Radicalism and Global Jihad (Washington, D.C: Georgetown University Press, 2009). 
suasana. $^{2}$ Keduanya mewakili dua unsur dasar manusiawi, yaitu dorongan untuk melakukan kerusakan dan kekerasan serta dorongan kepada kesucian dan kesakralan.

Kelahiran radikalisme Islam, sebagaimana dikemukakan oleh Muzakki, disebabkan karena kontribusi penting berbagai faktor, yaitu sikap represi politik penguasa, perampasan hak-hak sosial-ekonomi masyarakat, globalisasi, dan dukungan Saudi Arabia dalam berbagai aspek. ${ }^{3}$ Selain itu, peran pendidikan Islam pesantren tidak dapat dinafikan. Ia sangat menentukan kehadiran bibit-bibit potensial radikalisme Islam yang disebabkan pemahaman keagamaam kiai dan ustaż-ustaż nya yang sangat sempit. $^{4}$

Dalam konteks Bima, radikalisme Islam yang paling kuat sangat ditentukan oleh doktrin ideologis pesantren. Pesantren adalah lembaga pendidikan Islam yang menerapkan dua model kurikulum sekaligus, yaitu kurikulum Kemenag dan kurikulum pondok. Kurikulum yang terakhir ini diterapkan dengan dua pola yaitu, "pola terang dan pola gelap". Pola terang yaitu penerapan kurikulum yang dilakukan secara terangterangan, bisa diamati atau dilihat oleh siapa saja, dan tidak menimbulkan kecurigaan karena tidak terkait dengan doktrinasi ideologis radikalisme Islam. Adapun pola gelap yaitu penerapan kurikulum secara sembunyi-sembunyi (hidden curriculum) dan hanya bisa diketahui dan dirasakan oleh warga pesantren serta mengandung transmisi ideologi radikalisme Islam.

Selain karena adanya hidden curriculum yang diterapkan di pesantren (termasuk di Bima), terdapat beberapa peristiwa yang menyebabkan wilayah paling timur propinsi Nusa Tenggara Barat ini rawan radikalisme. Pertama, terjadinya peristiwa penangkapan terhadap beberapa ustaż yang diduga berkaitan dengan radikalisme pada pebruari 2011. Kedua, digagalkannya rencana aksi teror yang dilakukan oleh kelompok Mujahidin Indonesia Timur (MIT) dan kelompok Bima. ${ }^{5}$

Berdasarkan beberapa peristiwa tersebut maka pada kunjungan kerjanya ke Mataram Nusa Tenggara Barat, bertepatan pada Selasa 29 Maret 2016, kepala BNPT RI Inspektur Jenderal Polisi Tito Karnavian menyatakan bahwa Bima merupakan kawasan "zona merah" penyebaran faham radikalisme,. ${ }^{6}$ Pernyataan ini kiranya merupakan reason tersendiri yang sangat menguatkan untuk dilakukannya pembinaan sekaligus pendampingan bagi para kiai (TGP) dan para ustaż sebagai unsur utama pesantren, yang menjadi subjek kegiatan pengabdian ini. Mengingat keduanya merupakan sosok

\footnotetext{
${ }^{2}$ Ahmad Norma Permata, Agama dan Terorisme (Surakarta: Muhammadiyah University Press, 2006).

${ }^{3}$ Akh Muzakki, "The Roots, Strategies, and Popular Perception of Islamic Radicalism in Indonesia" 08, no. 01 (2014): 22.

${ }^{4}$ M. Amin Abdullah, Pendidikan Agama Era Multikultural Multireligius (Jakarta: PSAP, 2005).

5 https://news.detik.com/berita/d-3534677/2-orang-terduga-teroris-ditangkap-di-bima-ntb/. Diakses 05 Januari 2018.

6 https://sketsanews.com/555744/ntb-menjadi-zona-merah-penyebaran-faham-radikalisme/. Diakses 15 Maret 2018
} 
yang sangat potensial dalam menenamkan atau justru turut menangkal radikalisme berbasis pesantren.

Kiai merupakan elemen yang paling esensial dalam suatu pesantren. ${ }^{7}$ Kiai tidak hanya dapat disebut sebagai guru, tetapi juga sebagai pengganti ayah bagi para santri yang bertanggungjawab untuk membina dan memperbaiki tingkah laku dan moral para santri. ${ }^{8}$ Kiai merupakan sumber mutlak dari kekuasaan dan kewenangan (power and authority) dalam kehidupan dan lingkungan pesantren. Tidak seorang pun santri atau orang lain yang dapat melawan kekuasaan kiai, kecuali kiai lain yang lebih besar pengaruhnya. Dalam persepsi santri, bahwa kiai merupakan seorang yang memiliki kelebihan dan sangat percaya kepada diri sendiri, baik dalam soal-soal pengetahuan keislaman maupun dalam bidang kekuasaan dan manajemen pesantren. ${ }^{9}$

Para kiai dengan kelebihan pengetahuannya dalam Islam, senantiasa dipahami sebagai seorang yang dapat memahami keagungan Tuhan dan rahasia alam, sehingga dengan demikian dianggap memiliki posisi yang tidak dapat disandingkan dengan masyarakat biasa. Dalam beberapa hal, kiai menunjukkan eksistensi mereka dalam bentuk-bentuk pakaian yang sama dengan pakaian orang Arab sebagai simbol kealimannya. ${ }^{10}$

Di Bima Nusa Tenggara Barat, kiai diistilahkan dengan tuan guru. Jika tuan guru mengelola satu atau lebih pesantren, maka disebut dengan Tuan Guru Pesantren (selanjutnya disingkat dengan TGP). Sebagaimana kiai di Jawa, TGP di Bima juga memainkan peran dan fungsi yang sama. Para TGP merupakan referensi berjalan bagi santri, bahkan bagi masyarakat di luar pesantren. Demikian juga dengan ustaż, hanya saja yang disebut terakhir ini sebagai second figure atau referensi kedua di lingkungan pesantren.

Ustaż adalah pendidik atau guru yang mengajar pada pondok pesantren, sedangkan TGP adalah pendiri, pengasuh, pemimpin tertinggi di lingkungan pesantren. Bagi masyarakat Bima, kedua entitas atau unsur resources pesantren ini adalah figur atau pemimpin karismatik dalam istilah Weber dan cultural brokers dalam istilah Geertz, yang menjadi panutan bagi masyarakat dan santri. Mereka memegang kunci penting ke mana doktrin-doktrin agama akan ditransmisikan, ke mana biduk agama akan dibawa, apakah kea rah consensus dan kompromi yang menyejukkan atau ke arah pertentangan, mutual distrust dan kekerasan. ${ }^{11}$ Dalam pandangan masyarakat dan santri, TGP adalah figur pertama sedangkan ustaż adalah figur kedua. Peran keduanya sama-sama melakukan transformasi pengetahuan agama kepada para santri. Transformasi pengetahuan agama secara informal lebih banyak diperankan oleh TGP, sedangkan ustaż lebih banyak berperan aktif dalam kegiatan formal, walaupun pada

\footnotetext{
${ }^{7}$ Zamakhsari Dhofier, Tradisi Pesantren (Jakarta: LP3ES, 1996).

${ }^{8}$ Ibid

${ }^{9}$ Ibid

${ }^{10}$ Ibid

${ }^{11}$ Abdullah, Pendidikan Agama Era Multikultural Multireligius., 19.
} 
waktu tertentu kedua unsur tersebut dapat berganti peran dalam mentransformasikan pengetahuan agama kepada santri.

Berdasarkan data dari Badan Pusat Statistik Kota Bima Tahun 2015, di Kota Bima Nusa Tenggara Barat terdapat 14 buah pesantren ${ }^{12}$ (dengan ciri khasnya masingmasing), 3.451 santri, 13 orang $\mathrm{TGP}^{13}$, dan sejumlah ustaż mukim (yang tinggal di pesantren) dua sampai lima orang dalam masing-masing pesantren. ${ }^{14}$ Ke 13 orang TGP dan sejumlah ustaż yang mukim di pesantren inilah yang menjadi subyek dampingan.

Dari data tersebut, bahwa TGP dan ustaż merupakan dua unsur utama pesantren yang sangat menentukan eksistensi santri dan pesantrennya. Jumlah TGP dan ustaż pada masing-masing pesantren sangat potensial untuk mentransformasikan ilmu-ilmu agama kepada santri. Sebagaimana yang dikemukakan oleh Weber, bahwa kepemimpinan yang biasa diterapkan pada lembaga pendidikan tradisional mengikuti pola kepemimpinan karismatik.

Selain potensial dalam hal tersebut, pesantren sangat berpotensi pula untuk melahirkan radikalisme Islam. Pada saat dilakukan observasi tentang kegiatan transmisi pengetahuan oleh ustaż dan TGP, pemahaman tentang nilai-nilai multikultural masih terbatas pada aspek suku dan bangsa. Sedangkan dalam aspek budaya, gender, dan agama mereka lebih subjektif-diskriminatif atau menafikan realitas multikultural. ${ }^{15}$ Sejumlah radikalisme Islam yang bermuara pada tindakan kekerasan kepada pihak lain di Kota Bima dominan dilakukan oleh alumni pesantren.

Hasil penelitian tentang gerakan Islam radikal di Kota Bima, menunjukkan bahwa radikalisme Islam dan kekerasan bersumber dari lembaga-lembaga kajian Islam, SDIT, SMPIT, dan pondok pesantren. ${ }^{16}$ Karena itu, bukan suatu yang mengada-ada jika keilmuan yang ditransmisikan oleh ustaż dan TGP kepada santri mengandung radikalisme Islam. Demikian juga kajian yang dilakukan oleh Abdul Malik, bahwa di pesantren terjadi radikalisasi pemahaman Islam yang dilakukan oleh para ustaż melalui kurikulum tersembunyi. ${ }^{17}$ Kurikulum tersembunyi sering diterapkan pada saat-saat tertentu pada malam hari. ${ }^{18}$ Studi yang dilakukan oleh Nurrohman mengukuhkan kajian sebelumnya, bahwa pimpinan pesantren juga mengajarkan radikalisme Islam yang bermuara pada tindak kekerasan atas nama agama - walaupun secara diam-diam. ${ }^{19}$

\footnotetext{
${ }^{12}$ Adapun PP yang dimaksud adalah PP Darul Hikmah, Imam Syafii, Al-Husainy, Khalid bin Walid, Ash-Shiddiqiyah, Nurul Mubin, Darul Furqan, Al-Ikhlas, Al-Ikhwan, Al-Khitab al Islamy, Darul Ulum wal Amal, Darul Muttaqin, dan Nurul Mubin. Data BPS tahun 2015.

${ }^{13}$ Dikutip dari Data Badan Pusat Statistik Kota Bima Tahun 2015.

${ }^{14}$ Studi pendahuluan pada 5-8 Maret 2017.

${ }^{15}$ Pengamatan pada PP Darul Hikmah dan Imam Syafii tanggal 8 Maret 2017.

${ }^{16}$ Husnatul Mahmudah dkk., "Akar Genealogis Gerakan Salafi di Kota Bima”, Penelitian Kelompok LP2M IAI Muhammadiyah Bima, 2015.

${ }^{17}$ Abdul Malik, "Jaringan Intelektual dan Ideologi Pesantren Salafi Jihadi: Studi pada Daerah 'Zona Merah' Terorisme Di Bima," 2018, 223-40.

${ }^{18}$ Malik., 223-40.

19 Nurrohman Nurrohman, "Pesantren Responses to Religious Tolerance, Pluralism and Democracy in Indonesia," International Journal of Nusantara Islam 2, no. 1 (June 9, 2014): 69-82,
} 
Doktrin-doktrin radikalisme Islam dalam pesantren adalah tindakan subjektif yang memandang pemahaman dan tindakan orang lain bukan suatu yang lazim dalam agama. Kecenderungan menyalahkan orang lain yang berbeda pemahaman dengan ustaż dan TGP atau kiai sering disebabkan karena lemahnya pemahaman tentang nilainilai multikultural dalam kehidupan beragama dan berbangsa. Kebenaran selalu diukur dengan kebenaran dalam perspektif subjektif para ustaż dan TGP itu sendiri. Itulah sebabnya mereka mentransmisikan ideologi Islam radikal. Keberadaan pola pendidikan pesantren yang demikian akan berdampak pada retaknya persatuan dan kesatuan umat.

Berdasarkan fakta kondisi subyek dampingan saat ini yang sangat subjektif memahami realitas multikultural, sehingga berpaham radikalisme Islam yang bermuara pada tindakan teror, maka ke depannya subyek dampingan yang diharapkan adalah dampingan yang obyektif memahami Islam. Oleh karena itu, yang diharapkan adalah pertama, perubahan pemahaman ustaż dan TGP terhadap Islam dari ekslusif (tertutup) ke inklusif (terbuka). Pemahaman yang ekslusif akan mengarah pada radikalisme Islam, sedangkan pemahaman yang inklusif akan menjunjung tinggi nilai-nilai multikultural. ${ }^{20}$ Kedua, ustaż dan TGP memahami Islam secara menyeluruh (universal), sehingga tidak mudah menyalahkan pemahaman dan praktik ritual agama dan budaya orang lain yang berbeda dari kelompok atau golongannya. Ketiga, tertransformasikannya nilai-nilai multikultural kepada warga pesantren (santri), seperti persamaan, keadilan, toleransi. sehingga output dari pesantren-pesantren di Kota Bima tidak menganut radikalisme Islam yang bermuara pada tindakan teror atas nama jihad di jalan Allah.

\section{Metode}

Pengabdian kepada masyarakat ini menggunakan metode Community-Based Research (CBR), yaitu penelitian bersama masyarakat untuk mengatasi permasalahan yang dialami oleh masyarakat. Dalam hal ini pelaku utama pengabdian adalah tim pengabdi bersama ustaż dan TGP sebagai dua entitas yang menjadi aset sebuah pesantren. Pesantren tidak akan dapat eksis dan dinamis bilamana kedua aset ini tidak berfungsi. Keduanya memiliki peran penting yang sangat menentukan keberadaan pesantren.

Metode $C B R$ memiliki kesamaan dengan pendekatan $C B P R$, yakni metode partisipatori yang juga dikembangkan sebagai cara untuk mendorong kerjasama antara peneliti akademisi dengan masyarakat, untuk mendapatkan dan mengembangkan penemuan yang tepat serta sebagai metode untuk menerjemahkan temuan penelitian menjadi perubahan yang bersifat praktis. Maka dalam $C B P R$, antara peneliti dengan

${ }^{20}$ Ruslan Ibrahim, "Pendidikan Multikultural: Upaya Meminimalisir Konflik dalam Era Pluralitas Agama," 2008, 112-14. 
masyarakat dapat saling mencari dan menemukan peran masing-masing melalui sebuah proyek penelitian. ${ }^{21}$

Senada dengan di atas, CBPR merupakan bentuk kerjasama antara kaum akademik berbasis pada identifikasi masalah atau isu yang ada dalam suatu masyarakat. $C B P R$ mengembangkan suatu proyek dari masyarakat, dimana mereka mambutuhkan suatu kekuatan untuk mewujudkan sebuah perubahan, maka secara metodologis masyarakat membutuhkan bantuan peneliti. ${ }^{22}$ Bahkan CBPR bertujuan untuk menghilangkan pertentangan antara peneliti dan masyarakat yang diteliti, dengan asumsi bahwa setiap orang akan berusaha memenuhi kebutuhannya dan untuk saling menjadi partner yang berkontribusi dalam suatu proyek penelitian. ${ }^{23}$

Transfer pengetahuan dalam $C B P R$ secara umum adalah membagi informasi antara peneliti dan komunitas partner. Proses transfer ini sangat penting untuk menjaga antusiasme dan memelihara momentum untuk mencapai suatu perubahan bagi komunitas masyarakat tersebut. Maka kunci kesuksesan CBPR terletak pada kapasitas masyarakat dan kerjasamanya dengan kaum akademisi serta tersedianya fasilitas dan intensitas dialog antara keduanya. ${ }^{24}$

Penggunaan metode $C B R$ sangat memungkinkan adanya kerjasama antara tim pengabdi dengan komunitas dampingan dalam melakukan setiap tahapan penelitian, mulai dari rancangan awal pengabdian, pengumpulan data dan analisis data, pelaksanaan kegiatan pengabdian atau aksi sampai diseminasi hasil pengabdian. Pendekatan ini merupakan model pengembangan masyarakat dalam mengupayakan terwujudnya sebuah tatanan kehidupan sosial dimana masyarakat menjadi pelaku dan penentu upaya pembangunan di lingkungannya. Dalam hal ini, ustaż dan TGP sebagai dua unsur masyarakat pelaku yang menggerakkan pesantren merupakan pelaku sekaligus penentu upaya pencegahan radikalisme Islam berbasis pesantren, khususnya di Kota Bima.

Menurut Joanna Ochocka, terdapat empat tahapan dalam penelitian CBR, yaitu: laying foundation; peletakan dasar, research planning; perencanaan penelitian, information gathering and analysis, pengumpulan dan analisis data, acting on finding, aksi atas temuan. Secara lengkap keempat tahapan $C B R$ dapat terlihat pada bagan di bawah ini:

${ }^{21}$ E. Lightfoot, J. S. McCleary, and T. Lum, "Asset Mapping as a Research Tool for CommunityBased Participatory Research in Social Work," Social Work Research 38, no. 1 (March 1, 2014): 59-64, https://doi.org/10.1093/swr/svu001.

22 Patricia Leavy, Research Design: Quantitative, Qualitative, Mixed Methods, Arts-Based, and Community-Based Participatory Research Approaches (New York; London: Guilford Press, 2017), 224.

${ }^{23}$ Sarah Maiter et al., "Reciprocity: An Ethic for Community-Based Participatory Action Research," Action Research 6, no. 3 (September 2008): 305-25, https://doi.org/10.1177/1476750307083720.

24 Karen Hacker et al., "Community Capacity Building and Sustainability: Outcomes of Community-Based Participatory Research," Progress in Community Health Partnerships: Research, Education, and Action 6, no. 3 (2012): 349-60, https://doi.org/10.1353/cpr.2012.0048. 


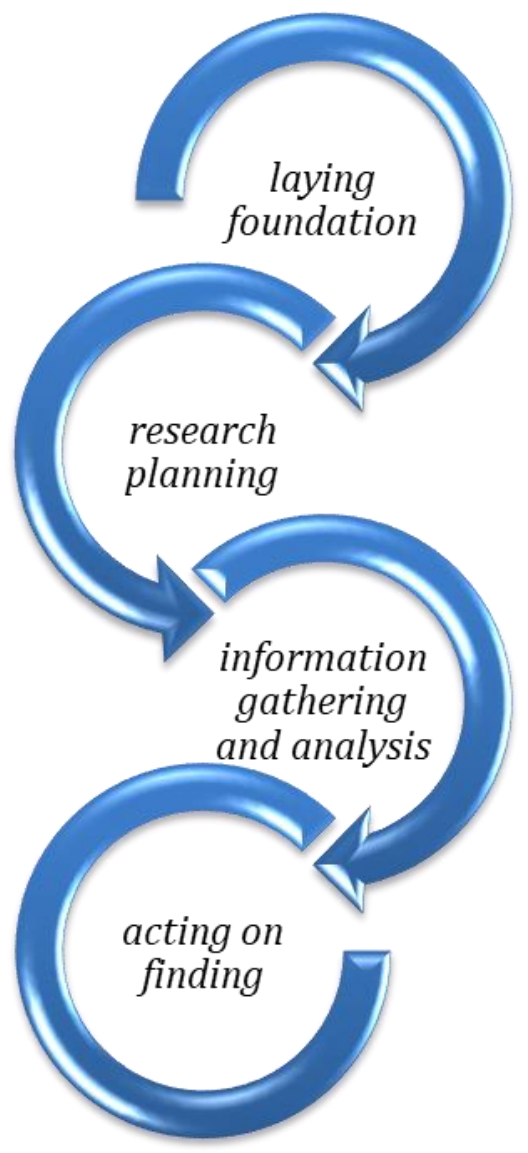

Gambar 1. Bagan alur/tahapan CPR hasil modifikasi tim pengabdi. ${ }^{25}$

Berdasarkan empat tahapan tersebut, secara sistematis implementasinya dalam pengabdian ini adalah sebagai berikut:

Pertama, laying foundation; peletakan dasar. Tahapan ini merupakan tahapan pertama dalam pengabdian, mencakup studi pendahuluan tim pengabdi ke beberapa pesantren yang ada di wilayah Kota Bima. Studi pendahuluan ini untuk memastikan beberapa pesantren yang layak dikategorikan sebagai pesantren yang aktif atau pasif, sehingga tim pengabdi tidak salah dalam menentukan subyek dampingan. Meskipun berdasarkan data dari Badan Pusat Statistik Kota Bima Tahun 2015, ${ }^{26}$ di Kota Bima Nusa Tenggara Barat terdapat 14 buah pesantren ${ }^{27}$ akan tetapi sesuai hasil observasi awal hanya terdapat 8 (delapan) pesantren yang bersedia untuk aktif dalam kegiatan

${ }^{25}$ Abdul Muhid et al., "Perubahan Perilaku Open Defecation Free (ODF) melalui Program Sanitasi Total Berbasis Masyarakat (STBM) di Desa Babad Kecamatan Kedungadem Kabupaten Bojonegoro," Engagement: Jurnal Pengabdian Kepada Masyarakat 2, no. 1 (May 30, 2018): 99-119, https://doi.org/10.29062/engagement.v2i1.27.

${ }^{26}$ Dikutip dari Data Badan Pusat Statistik Kota Bima Tahun 2015.

${ }^{27}$ Adapun PP yang dimaksud adalah PP Darul Hikmah, Imam Syafii, Al-Husainy, Khalid bin Walid, Ash-Shiddiqiyah, Nurul Mubin, Darul Furqan, Al-Ikhlas, Al-Ikhwan, Al-Khitab al Islamy, Darul Ulum wal Amal, Darul Muttaqin, dan Nurul Mubin. Data BPS tahun 2015. 
pengabdian, sehingga hanya mereka yang bersedia saja yang dijadikan sebagai subyek dampingan.

Desain program pengabdian telah dimulai dan direncanakan sejak tahapan ini. Beberapa aktifitas dalam pematangan desain program diantaranya adalah melakukan koordinasi tim pengabdi dan mengkaji lebih mendalam melalui observasi di komunitas dampingan. Selain itu, koordinasi dan konsolidasi tim pengabdi juga terus dilakukan untuk tetap membangun persepsi bersama dalam melaksanakan pengabdian masyarakat agar mendapatkan hasil yang maksimal. Desain program pengabdian ini juga didasarkan atas data awal di lapangan, baik hasil observasi, dokumentasi maupun wawancara mendalam dengan berbagai stakeholders pesantren. ${ }^{28}$

Selain sebagai kegiatan observasi awal, tahapan ini juga merupakan ajang pertemuan tim pengabdi dengan TGP dan para stakeholders masing-masing pesantren tersebut. Pertemuan awal ini sebagai tahap pembuka yang membahas seputar rencana pendampingan sekaligus sebagai upaya koordinasi dengan para ustaż yang bermukim di beberapa pesantren.

Tahapan pertama menunjukkan hasil yang cukup menggembirakan. Para TGP dan ustaż merasa tidak keberatan untuk ikut berpartisipasi aktif dalam kegiatan pendampingan. Terbukti dengan adanya kesediaan dan kehadiran beberapa utusan dalam kegiatan FGD. Selain itu juga mereka tetap bersedia berdiskusi dengan tim pengabdi selama kegiatan diskusi evaluatif berlangsung serta sambutan hangat ketika berjalannya visiting community.

Kedua, research planning; perencanaan penelitian. Dalam tahapan kedua ini tim pengabdi mulai memaparkan secara lebih terperinci mengenai rencana kegiatan apa saja yang akan diselenggarakan selama kegiatan pendampingan. Kegiatan mencakup $F G D$, diskusi evaluatif dan visiting community. Selain itu juga tim pengabdi mengusulkan jumlah utusan yang kira-kira dapat dilibatkan secara aktif dalam masing-masing kegiatan tersebut.

Secara garis besar para TGP merespon baik rincian rencana pendampingan ini, namun hanya sedikit diantara mereka yang besedia berperan aktif di setiap kegiatan. Mereka justru lebih mempercayakan kepada para ustaż maupun santri senior yang memang dipercaya mampu menjadi perwakilan pesantren mereka, padahal tim pengabdi mentargetkan 1 orang TGP dan 5 orang ustaż dari masing-masing pesantren untuk menjadi peserta aktif $F G D$.

Ketiga, information gathering and analysis, pengumpulan dan analisis data. Setelah tim pengabdi melakukan sharing dengan para TGP dan ustaż mengenai rancangan kegiatan dalam pengabdian ini, kemudian dilanjutkan dengan menggali informasi dari mereka mengenai kemungkinan serta kendala-kendala yang bisa saja ditemui ke depannya. Di antara kemungkinan tersebut adalah ketidakhadiran para

${ }^{28}$ M Daimul Abror et al., "Pendampingan Integrated Policy and Management System Tata Kelola Sampah Di Pesantren Ngalah Sengonagung Purwosari Pasuruan," Engagement : Jurnal Pengabdian Kepada Masyarakat 3, no. 2 (November 2019): 234-5. 
undangan dalam $F G D$, sulitnya mencari titik temu mengenai waktu pelaksanaan kegiatan dengan kegiatan beberapa pesantren maupun kesulitan-kesulitan tehnis lain di lapangan.

Sebagai tahap negotiating meaning and learning, tahapan ini merupakan pemaknan dan pembelajaran melalui pengumpulan, analisis dan penginterpretasian data bersama komunitas dampingan. Maka pada tahapan ini tim pengabdi melakukan diskusi mendalam sebagai upaya negosiasi pemikiran dengan para ustaż dan TGP tentang radikalisme Islam yang disinyalir salah satunya justru bersumber dari pesantren. Bahkan pandangan yang lebih ekstrim menyatakan bahwa radikalisme Islam di Bima dilahirkan dari rahim pesantren itu sendiri.

Pandangan ini tentu bukan hal mudah untuk diterima para stakeholders pesantren. Mengingat lembaga yang mereka bina pada hakekatnya adalah bertujuan untuk ber-tafaqquh fil-din dan menegakkan Islam dan bukan sebaliknya. Oleh karena itu, untuk menemukan titik temu inilah perlu dilakukannya negosiasi tersebut, sehingga dalam pelaksanaan kegiatan pengabdian tidak lagi ditemukan kendala yang cukup berarti.

Keempat, acting on findings, aksi atas temuan. Tahapan terakhir merupakan tahap pelaksanaan pengabdian yang mencakup strategi $F G D$, diskusi evaluatif dan visiting community. FGD bertujuan untuk membuka wawasan dasar para ustaż dan TGP tentang pentingnya nilai-nilai multikultural dalam pesantren sekaligus sebagai sarana sharing informations baik antara peserta $F G D$ dengan tim pengabdi sendiri, maupun antara sesama peserta $F G D$ yang berasal dari beberapa pesantren dengan latar belakang fokus keilmuan berbeda. Kegiatan FGD ini dilaksanakan di lantai II Gedung Serba Guna (GSG) Muhammadiyah Bima, pada hari Kamis tanggal 06 September 2018, yang disupport juga oleh Fakultas Tarbiyah dan LP2M Institut Agama Islam Muhammadiyah Bima.

Sebagai tindak lanjut dari kegiatan ( $F G D$ ), tim pengabdi mengunjungi dan mengadakan diskusi internal pada masing-masing pondok pesantren tersebut, sebagai bentuk evaluasi sejauh mana para TGP dan para ustaż memahami nilai-nilai multicultural yang telah dipaparkan dalam kegiatan FGD. Selain itu, untuk memastikan apakah TGP dan ustaż sudah mulai mentransformasikan nilai-nilai multikultural kepada para santri dan seluruh warga pesantren secara lebih luas. Melalui diskusi tim pengabdi mendapatkan data alamiah aktivitas warga dan kondisi pesantren melalui wawancara tak terstruktur dan observasi langsung. Kegiatan ini termasuk dalam diskusi evaluatif dan visiting community sekaligus.

Untuk mendukung terselenggaranya kegiatan pengabdian ini, tim bekerjasama dengan beberapa unsur, di antaranya: Pertama, Ustaż dan TGP selain sebagai unsur utama pesantren, merupakan peserta dampingan penuh yang akan mengikuti seluruh rangkaian kegiatan pengabdian kepada masyarakat. Kedua, Forum Komunikasi dan Silaturrahim Pondok Pesantren (FKSPP) Kota Bima. Keterlibatannya sebagai undangan dan yang akan mengkoordinasikan seluruh subyek dampingan. Ketiga, MUI, selain 
sebagai pembicara juga dihadirkan sebagai pengawal kegiatan. Mereka akan dilibatkan sebagai "korektor" tentang materi dari narasumber dan peserta dampingan untuk menghindari pemikiran yang berlebihan dalam liberalism dan normativisme. Jika terjadi demikian, maka MUI akan menengahinya. Keempat, Kemenag Kota Bima merupakan institusi Negara yang menaungi lembaga-lembaga pendidikan Islam baik madrasah maupun pesantren. Instansi ini akan dilibatkan sebagai pemberi sambutan sekaligus membuka secara resmi kegiatan FGD.

\section{Hasil dan Diskusi}

Ustaż dan TGP merupakan dua unsur utama pesantren yang sangat menentukan eksistensi santri dan pesantrennya. Jumlah TGP dan ustaż pada masing-masing pesantren sangat potensial untuk mentransformasikan ilmu-ilmu agama kepada santri. Sebagaimana yang dikemukakan oleh Weber, bahwa kepemimpinan yang biasa diterapkan pada lembaga pendidikan tradisional mengikuti pola kepemimpinan karismatik. Oleh karena itu, kedua unsur pesantren tersebut penting diundang sebagai peserta FGD.

Pada saat dilakukan kegiatan $F G D$, Tuan Guru senior sekaligus Ketua MUI Kabupaten Bima, TGH. Abdurrahim Haris, Lc., MA menyampaikan materi tentang konsep irhab dan radikalisme dalam Islam. Menurutnya, radikalisme sebenarnya tidak ada dalam Islam, tetapi merupakan kegiatan yang lazim dilakukan oleh non Muslim. Adanya radikalisme dalam Islam, menurutnya, muncul disebabkan perbedaan sikap politik dengan pemerintah, masyarakat tidak puas dengan kebijakan dan keputusan pemerintah. Selain itu juga mereka kebanyakan bersikap tekstualis dalam memahami ayat-ayat Alquran. Orang yang tekstualis memahami ayat-ayat Alquran cenderung mengajak orang lain untuk melakukan terror atau terorisme. Kelompok-kelompok tekstualis sering membuat pernyataan, misalnya: "barangsiapa yang memisahkan Irhab dengan Islam, maka dia kafir". 29

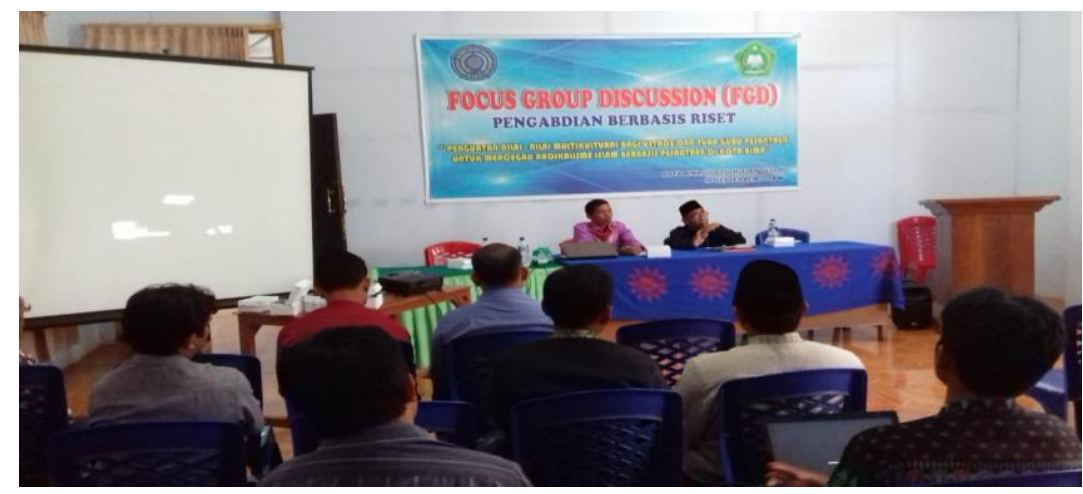

Gambar 2. TGH. Abdurrahim Haris, Lc., MA pada saat menyampaikan materi

${ }^{29}$ Nurrohman., 11-12. 
Dari uraian Tuan Guru senior tersebut, Ust. Ilham dari Pondok Pesantren AlHusainy mengajukan komentar, "saya tidak sependapat dengan tema kegiatan ini terutama istilah multikultural. Istilah multicultural adalah strategi orang non Muslim dalam menyamakan antara mukmin dan kafir, Islam dan Kristen, dan lain-lain. Apakah nantinya praktik multicultural ini "kalau ada orang Papua atau Irian Jaya yang melanjutkan pendidikan di pondok pesantren, apakah mereka menggunakan pakaian adat Koteka...? Dan bagaimana menurut tuan guru tentang konsep Irhab itu sendiri?". Berkaitan dengan hal itu, TGH Abdurrahim Haris, MA menanggapi bahwa "multicultural dalam hal ini adalah bukan yang berhubungan aqidah, tetapi berkaitan dengan masalah syariat kemasyarakatan dan kemanusiaan. Sedangkan terkait dengan pakaian adat masyarakat Papua dan Irian Jaya, mereka harus dapat menyesuaikan diri dengan etika dan kultur pesantren. Tidak mempertahankan pakaian adatnya sendiri, di lingkungan pesantren. Artinya mereka harus mampu menunjukkan diri dengan penuh penghormatan dan adaptasi dengan budaya setempat. Itulah multicultural yang benar".

Sementara terkait dengan konsep Irhab dalam Islam ${ }^{30}$, dalam penjelasannya, Abdurrahim mengatakan bahwa Irhab selalau disalah artikan dengan terorisme. Seakan-akan Allah swt. memerintahkan kaum Muslimin untuk berbuat teror (irhab). Padahal, sesuai dengan Surah An-Anfal: 60 tersebut, tidak berkaitan dengan terorisme, tetapi usaha atau kerja keras kaum Muslimin untuk menggentarkan musuh-musuh Allah. Oleh karena itu, Irhab bukan teror, melainkan menggentarkan.

Istilah menggentarkan musuh Allah, menurut Izza, adalah dalam konteks penyiapan sarana perang (dan bukan dalam konteks menebar ketakutan dengan cara kekerasan dan pembunuhan), yang tetap dilandasi dengan spirit mengedepankan perdamaian. ${ }^{31}$ Pemateri lain adalah Dr. Abdul Malik dengan materi "Melacak Akar Stigmatisasi Radikal Terhadap Pesantren". Menurutnya, walaupun stigma negatif tentang radikalisme Islam pesantren di Bima dilakukan oleh orang-orang sekuler dan liberal, tetapi jika dilacak lebih jauh, ternyata ada beberapa pesantren yang mentransmisikan ideologi radikal kepada santrinya. Pentransmisian ini dilakukan secara terbuka dan tertutup. Tetapi kebanyakan menggunakan cara tertutup dengan menerapkan hidden curriculum (kurikulum tersembunyi).

Namun, ketika disampaikan bahwa sebagian pesantren di Bima sengaja distigmatisasi radikal dan teroris oleh orang Barat atau orang-orang yang sekuler, para TGP dan ustaż semakin semangat dan serius mendengarkan penjelasn dari Abdul Malik. Bahkan seorang TGH. Muhammad Haris (TGP PP Darul Hikmah) mengajukan pertanyaan "apa alasan orang-orang sekuler menstigmatisasi pesantren dengan label radikal dan terror?. Dengan tegas Malik mengatakan bahwa orang-orang Barat pada umumnya tidak objektif dalam memandang Islam, apalagi pesantren sebagai pusat

\footnotetext{
${ }^{30}$ Pemateri menjelaskan Firman Allah dalam Alquran Surah Al-Anfal ayat 60

${ }^{31}$ Izza Rohman, "Jihad dan Qital dalam Al-Qur'an," in Reformulasi Ajaran Islam: Jihad, Khilafah, dan Terorisme (Bandung, 2017), 415-16.
} 
transformasi nilai-nilai Keislaman. Demikian juga dengan orang-orang Indonesia yang ingin mendapat keuntungan dari proyek Barat, pesantren selalu distigmakan negatif.

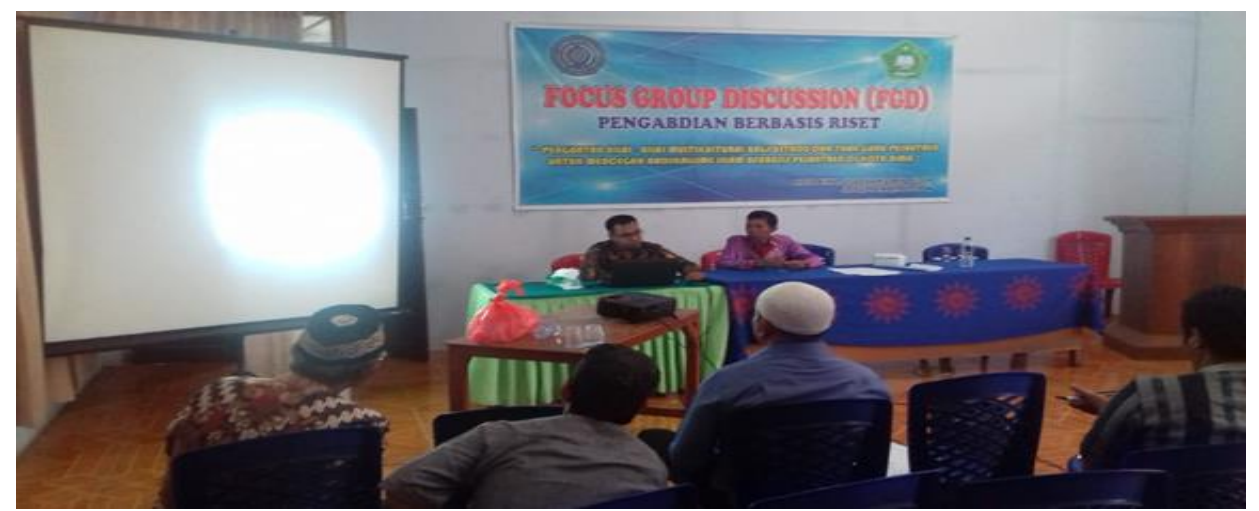

Gambar 3. Dr. Abdul Malik pada saat menyapaikan materi

Setelah dilakukan $F G D$, tim pengabdi melakukan kunjungan ke beberapa pondok pesantren dampingan. dalam rangka melakukan observasi dan diskusi evaluatif dari kegiatan FGD sebelumnya. Kegiatan ini dimaksudkan sebagai visiting community, sekaligus untuk mengamati sejauh mana perubahan pemahaman TGP dan ustaż. Pengamatan yang dilakukan oleh tim terutama pada malam hari setelah kegiatan shalat isya' berjamaah di masjid pondok. Yang menarik dari tausiyah yang disampaikan oleh TGP pada umumnya adalah penyampaian pemahaman baru konsep keanekaragaman dalam urusan syariah dan khuluqiyah. Artinya, nilai-nilai multicultural perlu diterapkan dalam aspek syariah dan akhlak santri, tetapi tidak pada segi akidah.

Diantara nilai-nilai multikultural yang di dalamnya terkandung juga nilai-nilai Islam yaitu: Pertama, konsep as-sawiyah (kesamaan), yakni dalam Islam derajat manusia adalah sama bagi seluruh hamba dan yang membedakannya secara kualitatif hanyalah ketakwaannya. Artinya Islam tidak membedakan ras, etnis, bahasa maupun suku bangsa. Dari manapun seseorang berasal, bahasa apapun yang digunakan dan apapun jenis kulit dan etnis yang dimiliki tidak menjadi batasan bagi seseorang untuk mencapai derajat takwa selama menjalankan perintah Allah dan menjauhi laranganNya.

Konsep kedua adalah al-'adalah (keadilan) terhadap semua orang (QS. An-Nisa': 58) sehingga dapat mencegah perilaku korup, serakah dan nepotisme. Sikap adil juga akan membuat seseorang mampu menempatkan setiap persoalan pada porsi yang seimbang, sehingga apapun permasalahan akan dapat dihadapi secara bijak tanpa perlu mempertimbangkan kepentingan-kepentingan pribadi dan golongan.

Ketiga adalah konsep kebebasan atau kemerdekaan (al-hurriyyah) yang memandang manusia memiliki kebebasan untuk menentukan sendiri pilihan apapun, sebagaimana termaktub dalam QS. Al-Baqarah ayat 256. Jika berpatokan pada konsep kebebasan dan atau kemerdekaan ini sangat relevan dengan konsep multikultural. Di mana juga mengakui adanya kebebasan dan kemerdekaan bagi siapapun untuk memilih yang sesuai dengan kebutuhan dan keinginannya. Tentu saja selama keinginan dan 
kebutuhan tersebut tidak melanggar keinginan dan kebutuhan orang lain. Mengingat kebebasan dan kemerdekaan setiap orang terkadang berbenturan atau berseberangan dengan kebebasan orang lain.

Terakhir adalah konsep toleransi (tasamuh) yang mampu menghargai, membiarkan atau membolehkan orang lain memiliki pandangan atau pilihan yang berbeda dengan kita. Toleransi dalam agama bukan berarti toleransi dalam masalahmasalah keagamaan melainkan sikap legowo dalam menjalani hubungan antar umat beragama dalam pergaulan kahidupan social bersama dan dalam hal kemasyarakatan dan kemaslahatan umum. Konsep toleransi ini merupakan konsekuensi dari konsep sebelumnya, yakni kebebasan dan kemerdekaan. Artinya ketika kebebasan dan kemerdekaan harus searah dengan aturan dan tata tertib, atau justru berseberangan dengan kebebasan dan kemerdekaan orang lain, maka sikap toleransi harus dikedepankan demi menjaga harmonisasi dan kedamaian.

Dengan demikian maka penguatan nilai-nilai di atas menjadi niscaya dan bersifat mendesak untuk segera diimplementasikan. Mengingat pesantren merupakan lembaga pendidikan yang disinyalir turut memberikan kontribusi dalam pembentukan generasi yang radikal. Sebagaimana diungkapkan Zuly Qodir bahwa: Jika diperhatikan secara seksama, aksi-aksi kekerasan yang berupa radikalisasi dengan dukungan agama dan institusi keagamaan selalu berhubungan dengan terorisme. ${ }^{32}$ Bahkan belakangan kaum santri yang mengalami radikalisasi, dalam perjalanannya berubah menjadi teroris. Beberapa pesantren disinyalir turut menyumbangkan aksi radikalisasi di Indonesia. Radikalisasi itu berangsur-angsur menjadi aksi terorisme yang menghalalkan segala cara untuk menyingkirkan orang lain yang dianggap berbeda dengan kelompoknya.

Sebagai hasil pengabdian yang patut diapresiasi serta sebagai wujud dari pendampingan baik melalui kegiatan FGD maupun diskusi evaluatif serta visiting community, terdapat beberapa pesantren yang bersedia mengundang tim pengabdi dalam khutbah Jum'at untuk menjadi khatib. Tentu saja hal ini bukan hal yang kebetulan semata. Akan tetapi ini mengindikasikan adanya kesadaran multicultural dalam pemahaman keagamaan para TGP dan ustaż, sekaligus mulai lahir keinginan untuk menanamkan kesadaran yang sama kepada para santri bahkan semua orang yang berkecimpung dalam pondok pesantren mereka. Karena bagaimanapun juga materi khutbah dapat dengan mudah didengar oleh semua orang di lingkungan pesantren, maka secara tidak langsung pula telah diupayakan pengenalan nilai-nilai multikultural kepada seluruh warga pesantren.

Secara terperinci alur pengabdian ini dapat dipahami melalui bagan berikut ini:

32 Zuly Qodir, "Jihad, Terorisme, dan Kaum Muda di Indonesia: Perspektif Sosiologis," in Reformulasi Ajaran Islam: Jihad, Khilafah, dan Terorisme (Bandung: Mizan, 2017). 
Bima sebagai

kawasan "zona

merah" penyebaran radikalisme
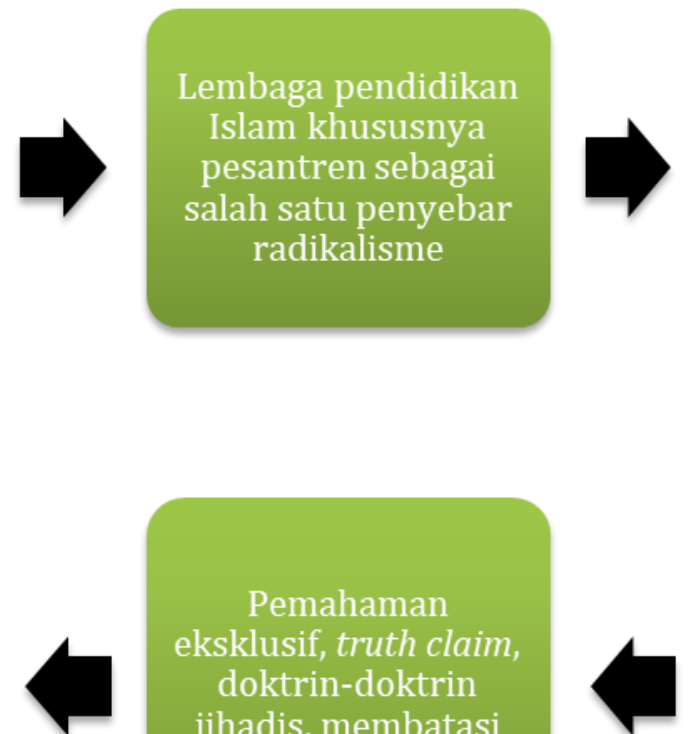

evaluatif dan visiting community

Kegiatan FGD sebagai transfer nilai-nilai multikultural, diskusi
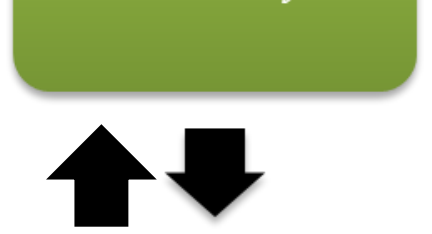

Pemahaman

keagamaan inklusif,

tumbuh sikap

moderasi beragama,

undangan khutbah

Jum'at dan

perumusan program pembelajaran.
Kurikulum ganda

"pola terang dan pola

gelap" kemenag dan

kemendikbud vs

hidden curriculum

dan kurikulum

pondok

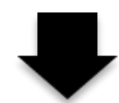

Pemahaman

eksklusif, truth claim,

doktrin-doktrin

jihadis, membatasi

hubungan sosial

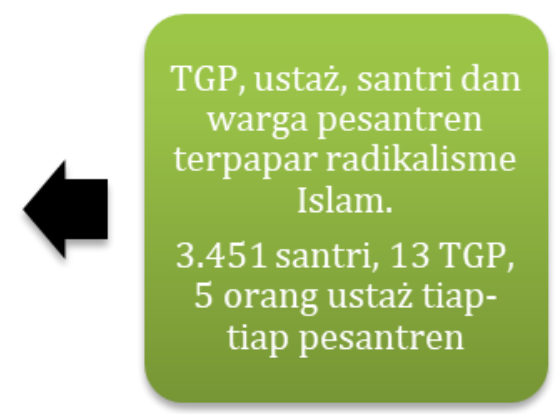

Gambar 4. Bagan Alur Pengabdian kepada Masyarakat

Kemudian, satu-satunya pondok pesantren yang bersedia melibatkan tim pengabdi terkait penyusunan program belajar pesantren adalah pondok pesantren Darul Hikmah, yang terletak di Lingkungan Soncolela, Kelurahan Matakando Kota Bima. Hal ini bukan keputusan yang mudah bagi pesantren ini, karena penyusunan program belajar sebenarnya adalah hal penting serta dapat dikatakan sebagai ruh dalam pembelajaran. Program pembelajaran sebagai penentu ke mana pondok pesantren akan di bawa, apakah akan menyuburkan radikalisme atau justru menanggulanginya sedini mungkin. Mengingat terdapat muatan hidden curriculum dalam kurikulum pesantren yang perlu mendapat perhatian dan perombakan secara substansial dan bersifat material.

Oleh karena itu, undangan penyusunan program pembelajaran Tahun Pelajaran 2019/2020 merupakan langkah preventif bagi pesantren Darul Hikmah sekaligus buah pendampingan dalam pengabdian ini. Pelibatan tim pengabdi ini pada hakikatnya juga 
memudahkan tim pengabdi untuk terus mengontrol dan memberikan kontribusi lebih konkrit bagi pesantren Darul Hikmah dalam hal pencegahan radikalisme Islam berbasis pesantren. Maka sebagai kegiatan lanjutan, tim pengabdi terus melakukan visiting community ke pesantren Darul Hikmah dan beberapa pesantren lain secara berkala dan berkelanjutan.

\section{Kesimpulan}

Kondisi awal pemahaman TGP dan ustaż mengenai nilai-nilai multikultural masih seputar pada aspek suku dan bangsa. Sedangkan dalam aspek budaya, gender, agama dan keyakinan lebih bersikap subjektif-diskriminatif. Artinya masih menafikan realitas multikultural yang majemuk. Pada kegiatan FGD, para TGP dan ustaż sangat antusias dan menunjukkan sikap lebih terbuka. Kadua unsur resources pesantren ini merasa memperoleh banyak pengetahuan baru yang lebih menyegarkan bagi rasa nasionalisme sebagai warga bangsa. Diskusi berjalan efektif melalui sharing pendapat dan pengalaman menjadi ajang perdebatan yang lebih dinamis dan progressif. Diskusi evaluatif dan visiting community yang dilakukan oleh Tim Pengabdi secara berkala mendapat sambutan hangat dari para TGP dan ustaż peserta FGD maupun warga pesantren yang lain sekaligus para santri.

Kurikulum ganda yang dianut pondok pesantren menuntut keterlibatan intensif sekaligus selektif dari para TGP dan ustaż sebagai penentu kebijakan, doktrin agama yang mana yang akan ditransmisikan dan bagaimana sebuah pesantren harus dicirikan, termasuk salah satunya adalah pemahaman tentang nilai-nilai multikultural. Karena sebenarnya nilai-nilai multicultural memiliki relevansi dengan ajaran Islam, mencakup: nilai kesamaan (al-sawiyah), keadilan (al-'adalah), kebebasan (al-hurriyyah) toleransi (tasamuh). Diskusi mengenai rancangan kurikulum yang anti radikalisme merupakan salah satu fokus pembicaraan dalam kegiatan diskusi evaluatif dan visiting community, yang dilakukan tim pengabdi beberapa kali ke beberapa pesantren dampingan.

Hasil pengabdian merupakan beberapa langkah preventif radikalisme Islam di pesantren, khususnya di Kota Bima. Salah satunya adalah undangan dari pesantren Darul Hikmah untuk mendiskusikan mengenai program pembelajarannya. Kegiatan ini merupakan strategi sekaligus peluang bagi tim pengabdi untuk menyisipkan nilai-nilai multicultural kepada mereka. Selain itu dalam pembelajaran dapat dirancang sedemikian rupa sehingga unsur-unsur radikalisme dapat dihindarkan atau bahkan ditiadakan sama sekali.

Selain itu, hasil yang bersifat praktis juga adalah kepercayaan beberapa pesantren kepada ketua tim (Ruslan) untuk mengisi khutbah Jum'at. Maka sebagai seorang khotib, tim pengabdi memiliki ruang resmi untuk menyampaikan nilai-nilai multicultural sebagai bagian dari nilai-nilai Islam yang bersifat universal. Tujuan khutbah tersebut tentu tidak menyimpang dari tujuan semula pengabdian dan program dampingan ini. Bahkan sebaliknya, khutbah menjadi sarana strategis untuk menguatkan 
pemahaman multikultural warga pesantren secara keseluruhan dan bersifat langsung. Mengingat selama ini hanya beberapa TGP, ustaż dan santri saja yang mendengar langsung atau berdiskusi langsung dengan tim.

Dalam rencana jangka panjang, kegiatan diskusi evaluatif dan visiting community tetap akan diupayakan dan bersifat berkelanjutan melalui kunjungan berkala. Rutinitas pertemuan ini tentu saja membuka jalan bagi tim pengabdi untuk terus melakukan pendampingan dan pembinaan sekaligus terus memupuk jalinan silaturrahmi yang telah terjalin dengan baik, sehingga dalam jangka panjang pencegahan radikalisme Islam berbasis pesantren dapat terkikis, perlahan tetapi pasti.

\section{Pengakuan}

Artikel ini merupakan ringkasan dari Laporan PkM berbasis riset. Adapun pihak-pihak yang terlibat dalam kegiatan ini adalah Direktorat Pendidikan Tinggi Keagamaan Islam, Direktorat Jenderal Pendidikan Islam, Kementerian Agama RI yang membiayai secara penuh, LP2M dan Fakultas Tarbiyah Institut Agama Islam Muhammadiyah Bima yang menfasilitasi kegiatan, perwakilan ustaż dan Tuan Guru Pesantren (TGP) se Kota Bima sebagai masyarakat dampingan, dan panitia yang sangat pro-aktif sampai kegiatan berakhir. Tanpa bantuan mereka, PkM ini tidak dapat berjalan sesuai dengan harapan. Oleh karena itu, kepada semua pihak yang terlibat Tim PkM menghaturkan terimakasih.

\section{Daftar Referensi}

Abdul Muhid, Sumarkan, Rakhmawati, and Lukman Fahmi. "Perubahan Perilaku Open Defecation Free (ODF) melalui Program Sanitasi Total Berbasis Masyarakat (STBM) di Desa Babad Kecamatan Kedungadem Kabupaten Bojonegoro." Engagement : Jurnal Pengabdian Kepada Masyarakat 2, no. 1 (May 30, 2018): 99119. https://doi.org/10.29062/engagement.v2i1.27.

Abdullah, M. Amin. Pendidikan Agama Era Multikultural Multireligius. Jakarta: PSAP, 2005.

Daimul Abror, M, Fathurrahman Amang, M Dayat, Zainul Ahwan, and Lukman Hakim. "Pendampingan Integrated Policy and Management System Tata Kelola Sampah Di Pesantren Ngalah Sengonagung Purwosari Pasuruan.” Engagement: Jurnal Pengabdian Kepada Masyarakat 3, no. 2 (November 2019): 230-44.

Dhofier, Zamakhsari. Tradisi Pesantren. Jakarta: LP3ES, 1996.

Hacker, Karen, Shalini A. Tendulkar, Catlin Rideout, Nazmim Bhuiya, Chau TrinhShevrin, Clara P. Savage, Milagro Grullon, Hal Strelnick, Carolyn Leung, and Ann DiGirolamo. "Community Capacity Building and Sustainability: Outcomes of 
Community-Based Participatory Research." Progress in Community Health Partnerships: Research, Education, and Action 6, no. 3 (2012): 349-60. https://doi.org/10.1353/cpr.2012.0048.

Ibrahim, Ruslan. "Pendidikan Multikultural: Upaya Meminimalisir Konflik dalam Era Pluralitas Agama," 2008, 112-14.

Leavy, Patricia. Research Design: Quantitative, Qualitative, Mixed Methods, Arts-Based, and Community-Based Participatory Research Approaches. New York; London: Guilford Press, 2017.

Lightfoot, E., J. S. McCleary, and T. Lum. "Asset Mapping as a Research Tool for Community-Based Participatory Research in Social Work." Social Work Research 38, no. 1 (March 1, 2014): 59-64. https://doi.org/10.1093/swr/svu001.

Maiter, Sarah, Laura Simich, Nora Jacobson, and Julie Wise. "Reciprocity: An Ethic for Community-Based Participatory Action Research." Action Research 6, no. 3 (September 2008): 305-25. https://doi.org/10.1177/1476750307083720.

Malik, Abdul. "Jaringan Intelektual dan Ideologi Pesantren Salafi Jihadi: Studi pada Daerah 'Zona Merah' Terorisme di Bima," 2018, 223-40.

Muzakki, Akh. "The Roots, Strategies, and Popular Perception of Islamic Radicalism in Indonesia" 08, no. 01 (2014): 22.

Nurrohman, Nurrohman. "Pesantren Responses to Religious Tolerance, Pluralism and Democracy in Indonesia." International Journal of Nusantara Islam 2, no. 1 (June 9, 2014): 69-82. https://doi.org/10.15575/ijni.v2i1.49.

Permata, Ahmad Norma. Agama dan Terorisme. Surakarta: Muhammadiyah University Press, 2006.

Qodir, Zuly. "Jihad, Terorisme, dan Kaum Muda di Indonesia: Perspektif Sosiologis." In Reformulasi Ajaran Islam: Jihad, Khilafah, dan Terorisme. Bandung: Mizan, 2017.

Rohman, Izza. "Jihad dan Qital dalam Al-Qur'an." In Reformulasi Ajaran Islam: Jihad, Khilafah, dan Terorisme, 415-16. Bandung, 2017.

Springer, Devin R., James L. Regens, and David N. Edger. Islamic Radicalism and Global Jihad. Washington, D.C: Georgetown University Press, 2009.

https://news.detik.com/berita/d-3534677/2-orang-terduga-teroris-ditangkap-dibima-ntb/. Diakses 05 Januari 2018.

https://sketsanews.com/555744/ntb-menjadi-zona-merah-penyebaran-fahamradikalisme/. Diakses 15 Maret 2018

Husnatul Mahmudah dkk., "Akar Genealogis Gerakan Salafi di Kota Bima”, Penelitian Kelompok LP2M IAI Muhammadiyah Bima, 2015.

Data Badan Pusat Statistik Kota Bima Tahun 2015. 